\title{
The diagnosis of excessive body mass and body fat in 18-year-old youth - assessment of comparability of results obtained on the basis of BMI and BIA methods
}

\begin{abstract}
Introduction. A systematic increase in the frequency of excessive body mass in young Poles is an argument supporting the need for identification persons with the increased risk. It is justified to test the level of comparability of the applied screening methods and criteria of diagnosing excessive body mass and body fat in the adolescent group.

Aim. To assess the comparability of the results in terms of frequency of diagnosing of overweight and body fat excessive content depending on the method and assessment criteria in 18-year-olds.

Material and methods. The study comprised 141 secondary school students (100 women and 41 men), with the age median of $17.8 \pm 0.5$ years. The measurements included height and body mass (to calculate the BMI) and assessment of the percentage of body fat content with two methods of bioelectric impedance in two bipolar versions: Tanita BC-570 and Omron BF-306.

Results. Excessive body mass, as defined by the BMI, was found in $12.1 \%$ of students. The incidence of diagnosing excessive contents of body fat in the organism depended on the method of measurement and criteria of results interpretation; $20.6 \%$ with the Tanita and $28.3 \%$ with the Omron method. The measurements with Tanita BC-570 scales demonstrated stronger correlation with BMI value $\left(\mathrm{p}<0.001 ; \mathrm{r}^{2}=0.34\right)$ than measurements with the Omron $\mathrm{BF}-306\left(\mathrm{p}<0.001 ; \mathrm{r}^{2}=0.16\right)$.

Conclusions. In young adults: 1 . the diagnosis of excessive body mass by BMI and measurement with use of the bioelectric impedance methods with two bipolar versions (Tanita BC-570, Omron BF-306) provided inconsistent results. 2. The proportion of young people with excessive body fat was greater than indicated by the BMI norms. 3. The measurement with Tanita BC-570 scales demonstrated stronger correlation with BMI values than by the ones with the Omron. 4. Critical approach to the applied methods is indispensable in screening studies of nutrition level among adolescents.
\end{abstract}

Keywords: body mass, body fat, body mass index, bioelectric impedance.

DOI: $10.2478 /$ pjph-2014-0027

\section{INTRODUCTION}

An increase in the frequency of excessive body mass in Poland [1] observed in the recent years is an argument supporting the need to conduct studies aimed at the identification of persons threatened on it, especially among the young [2]. Such a task can be concluded only on the condition of applying reliable methods and criteria for the assessment of the nutritional status. As far as the use of the weight and height-related body mass index (BMI) is concerned, the researchers' findings are consistent. Whitlock and other authors [3] proved its practicality in paediatric practice. In Poland, BMI is interpreted with respect to various criteria when referring to populations of children and young people [4]. Yet, as many authors believe, one should strive for the application of unified diagnostic criteria, irrespective of the age. Researchers believe that the use of BMI interpretation adopted for the adults in the group of adolescents in the final phase of puberty is justified [5]. The use of BMI does not allow a precise distinction between the body fat and the active tissues in the organism [6]. Determining the percentage of body fat and of uniform methods of its assessment is exceedingly important. Recently published papers suggest the need to identify metabolically obese normal-weight (MONW) individuals (persons with increased percentage of body fat). The authors argue that MONW leads to the development of metabolic and biochemical disorders, similar to those in the obese persons with metabolic syndrome $[7,8]$.

The percentage content of the body fat in the organism can be assessed indirectly, in ambulatory conditions, by performing anthropometric measurements $[9,10]$. In screening body constitution, the percentage of the body fat may also be assessed with the use of bioelectric impedance (BIA). The percentage of fat content in the body is based on differences in electric resistance (impedance) of the different tissues, with the control of the following variables: height, body mass, age and sex. The BIA technique is applied in tetrapolar and bipolar versions, the latter being more frequently used in ambulatory conditions because of the greater availability and ease of measurement [11]. 
Such comparison of the methods of body mass and fat content measurement and criteria of interpretation justifies the testing of the degree of comparability of the results obtained with different techniques. This evaluates the applicability of different methods available for determining excessive body mass and percentage of body fat (metabolically obesity), especially in the group of adolescents at the threshold of maturity.

\section{AIM}

To assess the comparability of the results in terms of frequency of diagnosing of overweight and body fat excessive content depending on the method and assessment criteria in 18-year-olds.

\section{MATERIAL AND METHODS}

Having obtained the permission of the Bioethical Commission of the Jagiellonian University (KBET/68/B/2006), school management, subjects, and their legal guardians, the study was conducted on a group of 141 secondary school students (100 women and 41 men). The mean age of the subjects was 17.80 .5 .

The anthropometric measurements were made consistently with the binding standards, and covered the measurements of height $(0.5 \mathrm{~cm}$ tolerance $)$ and body mass $(0.1 \mathrm{~kg}$ tolerance $)$. The measurements were made with the use of a mechanical column scales with eye-level beam of the Seca 711 type [12]. The BMI was calculated from the formula: body mass $(\mathrm{kg}) /$ height $(\mathrm{m})^{2}$ [13], and the results thus obtained were interpreted according to the standards of the World Health Organisation (WHO) [14].

To assess the percentage content of the body fat in the organism the BIA method in two bipolar versions (measured with Tanita BC-570 scales and Omron BF-306 Body Composition Monitor) was used. The results were interpreted according to the recommendations present in Polish literature, with the presence of $\geq 19 \%$ of body fat in total body mass in men and $\geq 29 \%$ in women being interpreted as excessive $[9,11]$. Second interpretation of the results acquired with the BIA method was also performed based on recommendations of producers of the devices used $[15,16]$.

The statistical analysis of the data was conducted with the Statistica 8.1 PL package. Descriptive statistical information and percentage values were calculated. The normality of distribution was verified with the Shapiro-Wilk test. To define the level of statistical significance, t-Student and Mann-Whitney U non-parametrical tests were used. The comparison of percentage values was conducted through a strata weight test. Assumptions concerning the dependence between two variables were verified using linear regression analysis. The results with the value of probability $p$ remaining below the 0.05 level $(\mathrm{p}<0.05)$ were considered significant.

\section{RESULTS}

Average body mass in women amounted to $59.2 \pm 9.1 \mathrm{~kg}$, and among men to $69.3 \pm 9.4 \mathrm{~kg}$ (with the group average at $62.2 \pm 10.3 \mathrm{~kg}$ ). The average BMI value in women was $22.0 \pm 2.9 \mathrm{~kg} / \mathrm{m}^{2}$, and among men $21.7 \pm 2.4 \mathrm{~kg} / \mathrm{m}^{2} ; \mathrm{p}=0.89$. According to BMI value, most subjects showed correct body mass $(79.4 \% ; n=112)$, in this $77 \%$ of women and $85.4 \%$ of men. Excessive body mass was detected in $12.1 \%(\mathrm{n}=17)$ of students, including $4.9 \%(n=2)$ of men, and $15.0 \%(n=15)$ of women; obesity was detected in only one woman in the study (Table 1). The percentage of subjects with excessive body mass did not depend significantly on gender $(p=0.09)$.

TABLE 1. Interpretation of the height and weight index (BMI) in the study group [14].

\begin{tabular}{lcccc}
\hline \multirow{2}{*}{ BMI $\left(\mathrm{kg} / \mathrm{m}^{2}\right)$} & \multicolumn{2}{c}{ Women } & \multicolumn{2}{c}{ Men } \\
\cline { 2 - 5 } & $\mathrm{n}$ & $\%$ & $\mathrm{n}$ & $\%$ \\
\hline$<18.5$ & 8 & 8.0 & 4 & 9.7 \\
\hline $18.5-24.9$ & 77 & 77.0 & 35 & 85.4 \\
\hline$\geq 25.0$ & 15 & 15.0 & 2 & 4.9 \\
\hline
\end{tabular}

BMI interpretation: $<18.5 \mathrm{~kg} / \mathrm{m}^{2}$ - underweight; $18.5-24.9 \mathrm{~kg} / \mathrm{m}^{2}$ - correct body mass; $\geq 25.0 \mathrm{~kg} / \mathrm{m}^{2}-$ excessive body mass [15].

The average percentage of body fat obtained with the use of Tanita BC-570scales in the whole group amounted to $20.6 \pm 8.7 \%$; among women $24.3 \pm 7.1 \%$; among men: $11.6 \pm 4.5 \% ; \mathrm{p}=0.001$ (Table 2). Using standardised criteria [9], excessive amount of body fat was detected in $21.3 \%$ $(n=30)$ of the subjects, including $27.0 \%(n=27)$ of women and $7.3 \%(n=3)$ of men (Table 3$)$. Interpreting the results in line with manufacturer recommendations [15], excessive percentage of body fat was detected in $15.6 \%(\mathrm{n}=22)$ of teens ( $21 \%$ women and $2.4 \%$ men); with the excess being significantly more often present in the case of women than men; $\mathrm{p}=0.005$ (Table 4).

Analysis with the use of the Omron BF-306 device turned out the average value of $28.3 \pm 8.0 \%$ of body fat for the entire group of subjects, $32.3 \pm 4.9 \%$; in the group of women and 18.5 \pm 5.1 among men (Table 2).

Interpreting these results according to standardised criteria [9], excessive percentage of body fat was diagnosed in $66.0 \%$ of the subjects $(n=93)$, including $74.0 \%(n=74)$ of women and $46.3 \%(n=19)$ of men (Table 3$)$. Using the recommendations of the manufacturer of the measuring device [16], excessive percentage of body fat was detected in every of examined subject (Table 4).

TABLE 2. Average values of the percentage of body fat (\% BF) in examined women and men, depending on the method of assessment used.

\begin{tabular}{cccccc}
\hline \hline \multirow{2}{*}{ VARIABLE } & \multicolumn{5}{c}{ Women } \\
\cline { 2 - 6 } & $\mathrm{n}$ & $\bar{x}$ & Min. & Max. & SD \\
\hline$\% \mathrm{BF}$ - Tanita BC-570 (\%) & 100 & 24.3 & 7.6 & 40.6 & 7.1 \\
\hline$\% \mathrm{BF}$ - Omron BF-306 (\%) & 100 & 32.3 & 21.0 & 43.2 & 4.9 \\
\hline \hline VARIABLE & \multicolumn{5}{c}{ Men } \\
\cline { 2 - 6 } & $\mathrm{n}$ & $\bar{x}$ & Min. & Max. & SD \\
\hline$\% \mathrm{BF}$ - Tanita BC-570 (\%) & 41 & 11.6 & 4.8 & 24.1 & 4.5 \\
\hline$\% \mathrm{BF}$ - Omron BF-306 (\%) & 41 & 18.5 & 8.5 & 30.1 & 5.1 \\
\hline
\end{tabular}


TABLE 3. Interpretation of the percentage of body fat (\% BF) in the subject based on standardised criteria available in Polish literature on the subject [9], depending on the method of assessment used.

\begin{tabular}{cccccccccc}
\hline \hline \multirow{2}{*}{\begin{tabular}{c} 
Method of assessment $\begin{array}{c}\text { Women } \\
\text { of } \% \text { BF }\end{array}$ \\
\cline { 2 - 11 }
\end{tabular}} & Norm & \multicolumn{1}{c}{$\begin{array}{c}\text { Above } \\
\text { norm }\end{array}$} & Norm & \multicolumn{3}{c}{$\begin{array}{c}\text { Above } \\
\text { norm }\end{array}$} \\
\cline { 2 - 10 } & $\mathrm{n}$ & $\%$ & $\mathrm{n}$ & $\%$ & $\mathrm{n}$ & $\%$ & $\mathrm{n}$ & $\%$ \\
\hline Tanita BC-570 & 73 & 73.0 & 27 & 27.0 & 38 & 92.7 & 3 & 7.3 \\
\hline Omron BF-306 & 26 & 26.0 & 74 & 74.0 & 22 & 53.7 & 19 & 46.3 \\
\hline
\end{tabular}

TABLE 4. Interpretation of the percentage of body fat (\% BF) in the subject based on interpretation criteria recommended by device manufacturer $[15,16]$, depending on the method of assessment used.

\begin{tabular}{|c|c|c|c|c|c|c|c|c|}
\hline \multirow{3}{*}{$\begin{array}{c}\text { Method of assessment } \\
\text { of } \% \text { BF }\end{array}$} & \multicolumn{4}{|c|}{ Women } & \multicolumn{4}{|c|}{ Men } \\
\hline & \multicolumn{2}{|c|}{ Norm } & \multicolumn{2}{|c|}{$\begin{array}{l}\text { Above } \\
\text { norm }\end{array}$} & \multicolumn{2}{|c|}{ Norm } & \multicolumn{2}{|c|}{$\begin{array}{l}\text { Above } \\
\text { norm }\end{array}$} \\
\hline & $\mathrm{n}$ & $\%$ & $\mathrm{n}$ & $\%$ & $\mathrm{n}$ & $\%$ & $\mathrm{n}$ & $\%$ \\
\hline Tanita BC-570 & 79 & 79.0 & 21 & 21.0 & 40 & 97.6 & 1 & 2.4 \\
\hline Omron BF-306 & 0 & 0.0 & 100 & 100.0 & 0 & 0.0 & 41 & 100.0 \\
\hline
\end{tabular}

The measurement performed on the group of people with BMI $\geq 25 \mathrm{~kg} / \mathrm{m}^{2}$ with Omron BF-306 device demonstrated excessive percentage of body fat in $94.1 \%(n=16)$ when the results were interpreted according to standardised criteria [9], and in all the subjects when the results were interpreted in accordance with manufacturer recommendations [16] (Table 5). Interpretation of the results of the measurements performed with Tanita BC-570 scales according to the criteria present in Polish literature [9] demonstrated excessive percentage of body fat in $70.6 \%(\mathrm{n}=12)$ people with BMI $\geq 25 \mathrm{~kg} / \mathrm{m}^{2}$, while interpretation based on the criteria recommended by the manufacturer [15] demonstrated excessive body fat in $58.8 \%(\mathrm{n}=10)$ subjects (Table 5$)$.

TABLE 5. Increased percentage of body fat (\% BF) in the organism, interpreted according to standardised criteria [9] and recommendations of the manufacturers of the measuring devices $[15,16]$, in people with $B M I \geq 25 \mathrm{~kg} / \mathrm{m}^{2}$, depending on the method of assessment applied.

\begin{tabular}{|c|c|c|c|c|}
\hline \multirow{3}{*}{$\begin{array}{c}\text { Method of assessment } \\
\text { of } \% \mathrm{BF}\end{array}$} & \multicolumn{2}{|c|}{ Women $(n=15)$} & \multicolumn{2}{|c|}{ Men $(n=2)$} \\
\hline & Norm & $\begin{array}{l}\text { Above } \\
\text { norm }\end{array}$ & Norm & $\begin{array}{l}\text { Above } \\
\text { norm }\end{array}$ \\
\hline & $\mathrm{n}$ & $\%$ & $\%$ & $\%$ \\
\hline
\end{tabular}

\begin{tabular}{lcccccccc}
\hline $\begin{array}{l}\text { Omron BF-306- } \\
\text { standardised criteria }\end{array}$ & 1 & 6.7 & 14 & 93.3 & 0 & 0.0 & 2 & 100.0 \\
\hline $\begin{array}{l}\text { Omron BF-306- } \\
\text { manufacturer } \\
\text { recommendations }\end{array}$ & 0 & 0.0 & 15 & 100.0 & 0 & 0.0 & 2 & 100.0 \\
\hline $\begin{array}{l}\text { Tanita BC-570 - } \\
\text { standardised criteria }\end{array}$ & 5 & 33.3 & 10 & 66.7 & 0 & 0.0 & 2 & 100.0 \\
\hline $\begin{array}{l}\text { Tanita BC-570 - } \\
\text { manufacturer } \\
\text { recommendations }\end{array}$ & 6 & 40.0 & 9 & 60.0 & 1 & 50.0 & 1 & 50.0 \\
\hline
\end{tabular}

Moreover, analyses of the measured amounts of percentage of body fat in the subjects were performed also for the group of people with BMI $<25 \mathrm{~kg} / \mathrm{m}^{2}$. In this group, the highest proportion of people with excessive percentage of body fat in the subjects was found in BIA-based analysis when using Omron BC-306 device and interpreting the acquired results in line with the manufacturer's recommendations $(100 \% ; n=124)$ [16], and the lowest $(9.7 \% ; n=12)$ when performing the measurements with Tanita BF570 scales and interpreting the results according to the criteria recommended by the manufacturer of the device [15] (Table 6).

TABLE 6. Increased percentage of body fat (\% BF) in the organism, interpreted according to standardised criteria [9], and manufacturer recommendations $[15,16]$ for the people with $\mathrm{BMI}<25 \mathrm{~kg} / \mathrm{m}^{2}$, broken down by the methods of assessment used.

\begin{tabular}{|c|c|c|c|c|c|c|c|c|}
\hline \multirow{3}{*}{$\begin{array}{c}\text { Method of assessment } \\
\text { of } \% \mathrm{BF}\end{array}$} & \multicolumn{4}{|c|}{ Women $(n=85)$} & \multicolumn{4}{|c|}{$\operatorname{Men}(n=39)$} \\
\hline & \multicolumn{2}{|c|}{ Norm } & \multicolumn{2}{|c|}{$\begin{array}{l}\text { Above } \\
\text { norm }\end{array}$} & \multicolumn{2}{|c|}{ Norm } & \multicolumn{2}{|c|}{$\begin{array}{l}\text { Above } \\
\text { norm }\end{array}$} \\
\hline & $\mathrm{n}$ & $\%$ & $\mathrm{n}$ & $\%$ & $\mathrm{n}$ & $\%$ & $\mathrm{n}$ & $\%$ \\
\hline $\begin{array}{l}\text { Omron BF-306- } \\
\text { standardised criteria }\end{array}$ & 25 & 29.4 & 60 & 70.6 & 22 & 56.4 & 17 & 43.6 \\
\hline $\begin{array}{l}\text { Omron BF-306- } \\
\text { manufacturer } \\
\text { recommendations }\end{array}$ & 0 & 0.0 & 85 & 100.0 & 0 & 0.0 & 39 & 100.0 \\
\hline $\begin{array}{l}\text { Tanita BC- } 570- \\
\text { standardised criteria }\end{array}$ & 68 & 80.0 & 17 & 20.0 & 38 & 97.4 & 1 & 2.6 \\
\hline $\begin{array}{l}\text { Tanita BC-570- } \\
\text { manufacturer } \\
\text { recommendations }\end{array}$ & 73 & 85.9 & 12 & 14.1 & 39 & 100.0 & 0 & 0.0 \\
\hline
\end{tabular}

The analysis of linear regression proved that, of the methods assessing the percentage of body fat in the organism, the measurement conducted with the use of Tanita BF-570 scales $\left(\mathrm{p}<0.001 ; \mathrm{r}^{2}=0.34\right)$ was the most correlated to the obtained BMI value. Lower coefficients of determination were obtained while analysing the BMI values with Omron BC-306 device $\left(\mathrm{p}<0.001 ; \mathrm{r}^{2}=0.16\right)$.

\section{DISCUSSION}

Excessive body mass present in the early period of life is not only a predisposition to obesity in adult life but also a recognised risk factor for the development of the metabolic syndrome and chronic conditions including those of the cardiovascular system $[17,18]$. The frequency of diagnosing excessive body mass in the population at developmental age [2] has significantly grown in the last decades. It might be influenced by the cultural, economic, and social changes taking place $[1,19]$.

Generally, the height and weight index (BMI) [9] is recognised as the most credible estimator of body mass. Moreover, a number of authors believe that excessive body mass in young people should be diagnosed according to the same methods and criteria as in adults. [5]. This interpretation was used in the our study.

In the group of the examined youth, excessive body mass, as expressed by BMI value was detected in $12.1 \%$ of subjects ( $15 \%$ women and $4.9 \%$ men), which does not significantly diverge from the results acquired by other Polish authors $[2,19]$. Similarly, studies conducted by Chrzanowska et al. [2] on a representative group of Kraków teenagers demonstrated more frequently the presence of excessive weight $(13 \%)$ and obesity (15\%) in boys as compared to girls $(9.7 \%)$, yet the difference was not significant between two genders. This data is difficult to compare directly to ours due to the different counts of the Chrzanowska et al. studied group, its age spread and the fact that the last series of study was conducted a decade ago [2]. 
Although easy to use, BMI provides no information about the composition, and even less so about the distribution, of body fat in the subjects. Numerous works suggesting the need for the identification of the MONW even among persons with correct body mass, also in the adolescent group [20] have been published in recent years. It is so as the excess of body fat favours a range of metabolic disorders, including insulin resistance, impaired glucose tolerance, dyslipidaemia, arterial hypertension, and activation of prothrombotic and proinflammatory processes [1]. Researchers use a variety of criteria to diagnose metabolic obesity. In the case of the paediatric population, their number includes waist circumference [20], and the value of the WtHR (waist-to-height ratio) index [1,20,21].

Applying the criteria used in WOBASZ (Wieloośrodkowe Ogólnopolskie Badanie Stanu Zdrowia Ludności) [21] study, MONW was found relevant for $1.4 \%$ of teenagers in our group, solely women. In the studies conducted by Przybylski et al. [20], the frequency of diagnosing MONW in the group of young people with correct body mass aged 16 to 18 amounted to $5.4 \%$ (waist circumference) or $5.0 \%$ (WtHR) [20], depending on the criterion applied.

Among the methods for assessment of the distribution of the body fat and defining its percentage compared to the fat-free body mass, densitometric techniques $[10,22]$ are believed to be "the golden standard". Today, they are rarely applied due to the high costs and low availability for everyday practice. However, the BIA became a popular method for assessment of body composition in medical studies. Literature emphasises its good correlation with BMI values [22] and high concurrence with other methods for the estimation of body fat [1]. Yet its worst drawback is the lack of population standards, and the need to maintain the same, repeatable conditions of measurements [23].

In the present study, two BIA methods in bipolar version (Omron BF-306 device and Tanita BC-570 scales) were used for the assessment of percentage of body fat in the organism.

In the study, regardless of the method applied and the interpretation criterion, the percentage of young people with excessive body fat in the organism was greater than the percentage of young people with excessive body mass diagnosed according to BMI values.

Socha et al. [24] acquired similar divergence between the results in studies of young non-obese women and men aged 20-29. Researchers compared various BIA methods used for the assessment of percentage of body fat and concluded that they should not be applied interchangeably due to great results divergences [24].

Of all the analysed methods of assessing the percentage of body fat in the body used in our studies, the optimum correlation between the BMI value and the result of the measurement was present in the case of Tanita BF-570 scales $\left(\mathrm{p}<0.001 ; \mathrm{r}^{2}=0.34\right)$. Moreover, the lowest share of young people with too high percentage of body fat in the group of people with BMI values of $<25 \mathrm{~kg} / \mathrm{m}^{2}$ was diagnosed when applying the BIA method based on the use of Tanita BF-570 scales and interpretation of the results obtained according to manufacturer recommendations [15].

\section{CONCLUSIONS}

In young adults:

1. The diagnosis of excessive body mass by BMI and measurement with the use of bioelectric impedance, the methods with two bipolar versions (Tanita BC-570, Omron BF-306) provided inconsistent results.

2. The proportion of young people with excessive percentage of body fat was greater than indicated by the BMI norms.

3. The measurement with Tanita BC-570 scales demonstrated stronger correlation with BMI values than by ones by the Omron.

4. Critical approach to applied methods is indispensable in screening studies of nutrition level among adolescents.

\section{REFERENCES}

1. Przybylska D, Kurowska M, Przybylski P. Otyłość i nadwaga w populacji rozwojowej. Hygeia Public Health. 2012;47(1):28-35.

2. Chrzanowska M, Gołąb S, Żarów R, et al. Trendy w otłuszczeniu ciała oraz występowanie nadwagi i otyłości u dzieci i młodzieży Krakowa w ostatnim trzydziestoleciu. Pediatr Pol. 2002;77(2):113-9.

3. Matusik P, Tendera-Małecka E, Nowak A. Metody stosowane w praktyce pediatrycznej do oceny stopnia odżywienia dzieci. Endokr Otyłość Zab Przem Mat. 2005;1(2):6-11.

4. Jodkowska M, Tabak I, Oblacińska A. Ocena częstość występowania nadwagi i otyłości u młodzieży w wieku 13-15 lat w Polsce przy zastosowaniu trzech różnych narzędzi badawczych. Przegl Epidemiol. 2007;61:585-92.

5. Szajewska H. Otyłość u dzieci. Nowa Pediatria. 2002;3:209-11.

6. Nawarycz T, Ostrowska-Nawarycz L. Wskaźnik masy ciała u dzieci i młodzieży łódzkiej w wieku szkolnym. Pol Merk Lek. 2007;23(136):264-70.

7. Bednarek-Tupikowska G, Matczak-Giemza M, Kubicka E, et al. Metaboliczna otyłość u osób z prawidłową masą ciała. Endokr Otyłość Zab Przem Mat. 2007;3(3):55-61.

8. Bednarek-Tupikowska G, Krzyżanowska-Świniarska B, Kubicka E, et al. W poszukiwaniu kryteriów rozpoznawania zespołu metabolicznej otyłości z prawidłowa masą ciała (MONW) - z uwzględnieniem wyników badań w 3 ośrodkach polskich. Endokr Otyłość Zab Przem Mat. 2009;5(3):123-4.

9. Bernas M. Clinical definition and assessment of obesity. Terapia. 2005;13(5):7-9.

10. Konstantynowicz J, Piotrowska-Jastrzębska J, Kaczmarski M, et al. Densytometryczna i antropometryczna ocena tkanki thuszczowej u młodzieży w wieku 13-19 lat. Endokrynol Ped. 2003;1(2):21-31.

11. Bolanowski M, Zadrożna-Śliwka B, Zatońska K. Badanie składu ciała - metody i możliwości zastosowania w zaburzeniach hormonalnych. Endokr Otyłość Zab Przem Mat. 2005;1(1):20-5.

12. Palczewska I, Szilágyi-Pągowska I. ABC zabiegów diagnostycznych i leczniczych w pediatrii. Ocena rozwoju somatycznego dzieci i młodzieży. Med Prakt Pediatr. 2002/03. [http://www.mp.pl/artykuly; 07.02.2011]

13. Fichna P, Skowrońska B. Otyłość i zespół metaboliczny u dzieci i młodzieży. Fam Med Fam Care Rev. 2008;10:269-78.

14. [http://apps.who.int/bmi/index.jsp?introPage=intro_3.html; 14.10.2013]

15. Gallagher D, Heo M, Jebb SA, et al. Healthy percentage body fat ranges: an approach for developing guidelines based on body fat index. An J Clin Nutr. 2000;72(3):694-701.

16. Deurenberg P, Yap M, van Staveren WA. Body mass index and percent body fat: a meta-analysis among different ethnic groups. Int J Obes Relat Metab Disord. 1998;22(12):1164-71.

17. Freedman D, Dietz WH, Srinivasan SR, Berengson G. The relation of overweight to cardiovascular risk factors among children and adolescents: The Bogalusa Heart Study. Pediatr. 1999;103:117582.

18. Katzmarzyk PT, Tremblay A, Perusse F. The utility of the international child and adolescent overweight guidelines for predicting coronary heart disease risk factors. J Clin Epidemiol. 2003;56:456-62. 
19. Kierzkowska B, Kłobusińska J, Stańczyk J. Otyłość u dzieci i młodzieży jako czynnik ryzyka chorób układu sercowo-naczyniowego związanych z miażdżycą. Pol Przegl Kardiol. 2006;8(3):204-7.

20. Przybylski P, Antonowicz D, Kurowska M. Wpływ zastosowanego wskaźnika oceny trzewnej tkanki tłuszczowej na częstość rozpoznawania oraz stopień zaawansowania otyłości metabolicznej z prawidłowa masą ciała u 16-18 letnich licealistów. Endokr Otyłość Zab Przem Mat. 2009;5(3):146-7.

21. Sygnowska E, Waśkiewicz A, Piwońska A. Metabolicznie otyli $\mathrm{z}$ prawidłową masą ciała w badaniu WOBASZ. Streszczenia - Endokr Otyłość Zab Przem Mat. 2009;5(3):124.

22. Romero-Corral A, Somers VK, Sierra-Johnson J, et al. Normal weight obesity: a risk factor for cardiometabolic dysregulation and cardiovascular mortality. Eur Heart J. 2010;31:737-46.

23. Majcher A, Pyrżak B, Czerwonogrodzka A, Kucharska A. Zawartość procentowa thuszczu $\mathrm{W}$ organizmie a parametry antropometryczne u dzieci z otyłością prostą. Dev Period Med. 2008;12(1):493-8.

24. Socha M, Karmińska K, Chwałczyńska A. Porównanie zawartości tkanki tłuszczowej u młodych nieotyłych kobiet i mężczyzn oznaczonej metodą bioimpedancji (wersja bi- i tetrapolarna) i metodą fotooptyczną. Endokr Otyłość Zab Przem Mat. 2010;6(1):18-25.

\section{Corresponding author}

Department of Medical and Environmental Nursing, Faculty of Health Sciences Jagiellonian University Medical College

25 Kopernika Str., 31-501 Kraków, Poland

tel.: 606-285-234

E-mail: e.kawalec@uj.edu.pl; e.kawalec@interia.pl 